\title{
Regulating Cultural Performances in Oceania: the Complicated Relationship between Law, Creativity and Cultural Property
}

Miranda Forsyth and Kalissa Alexeyeff

\section{QpenEdition}

\section{Journals}

Electronic version

URL: http://journals.openedition.org/jso/7489

DOI: $10.4000 /$ jso.7489

ISSN: $1760-7256$

Publisher

Société des océanistes

Printed version

Date of publication: 31 December 2016

Number of pages: 117-130

ISSN: 0300-953x

\section{Electronic reference}

Miranda Forsyth and Kalissa Alexeyeff, « Regulating Cultural Performances in Oceania: the Complicated Relationship between Law, Creativity and Cultural Property », Journal de la Société des Océanistes [Online], 142-143 | 2016, Online since 31 December 2018, connection on 19 April 2019. URL : http://journals.openedition.org/jso/7489; DOI : 10.4000/jso.7489 


\title{
Regulating Cultural Performances in Oceania: Relationships between Law, Creativity and Cultural Property
}

\author{
par
}

Miranda FORSYTH ${ }^{*}$ and Kalissa ALEXEYEFF ${ }^{* *}$

\section{ABSTRACT}

This paper explores a number of tensions around claims of rights over various aspects of cultural performance with a particular focus on the Cook Islands. We discuss the historical context of these tensions and trace the way in which certain anxieties and agendas have led to demands for, and the realisation of, new laws over cultural performances, most particularly the Copyright Act 2013 and the Traditional Knowledge Act 2013. We then discuss how such new regulatory frameworks have a potentially critical role to play in determining who has the rights to perform what, with effects that are likely to spill out from the confines of laws and court cases into popular discourses around claims over many manifestations of culture and creativity.

Keywords: copyright law, traditional knowledge, cultural performance, creativity, Cook Islands

\section{RÉSUMÉ}

Cet article examine les tensions en jeu dans la revendication de droits portant sur divers aspects de performances culturelles, avec un intérêt particulier pour le cas des îles Cook. Nous discutons le contexte historique dans lequel ces tensions ont émergé et retraçons la manière dont certaines craintes et intentions ont conduit à une demande - et parfois une mise en ouvre - de lois sur les performances culturelles, notamment le Copyright Act 2013 et le Traditional Knowledge Act 2013. Nous analysons ensuite la manière dont ces cadres législatifs peuvent jouer un rôle important dans la détermination de qui a le droit de faire quoi en matière de performance, avec des effets susceptibles de dépasser le cadre législatif et judiciaire pour sétendre aux discours communs sur les formes d'appropriation de nombreux aspects de la culture et de la créativité.

MoTs-CLÉs : législation sur le copyright, savoir traditionnel, performance culturelle, créativité, îles Cook

regulatory frameworks have a potentially critical role to play in determining who has the rights to perform what, with effects that are likely to spill out from the confines of laws and court cases into popular discourses around right to and claims over many manifestations of culture and creativity. Whilst the impetus for this legislation has been envisaged at a generalised level as protecting communities from misappropriation of their rights by outsiders, once the specific details particularly the Copyright Act 2013 and the Traditional Knowledge Act 2013. These new

This paper explores different sets of tensions in Cook Islands regarding claims of rights over aspects of cultural performance. We investigate historical anxieties and contradictory agendas regarding cultural performances. We then trace the way in which these anxieties and agendas have led to demands for, and the realisation of, new laws over cultural performances, most

*Associate Professor, School of Regulation and Global Governance (RegNet), ANu College of Asia \& the Pacific, The Australian National University, miranda.forsyth@anu.edu.au

${ }^{* *}$ Australian Research Council Future Fellow, School of Social and Political Sciences, The University of Melbourne, k.alexeyeff@unimelb.edu.au 
start to be worked through in legislation and in case-law, a range of complicated issues emerges: Who comprises communities with rights in certain aspects of cultural performances? Who are the outsiders? (Where do members of the large Cook Islands diaspora sit?) What impact are new property rights regimes likely to have on the long history of sharing and exchange of cultural performances across the region? What new types of agency and authority do state-based property rights regimes give to certain groups, and how do they disempower other groups? Through raising such questions and discussing how they play out in practice in the context of Cook Islands dance and music, we suggest that the tropes of culture that are used in such discourses, policy and laws problematically re-inscribe a model of culture as bounded and static that has been discredited in anthropological literature for a number of decades. In so doing, these new normative frameworks run the risk of having negative impacts upon the very social relationships and drivers of creativity and innovation that cultural performances are based. Whilst this paper focusses on Cook Islands, the issues discussed are also widespread in other Pacific island countries and in Pacific communities in the region and globally. Indeed, it is noteworthy that issues of cultural heritage and intellectual property are regularly discussed at international cultural events, such as the Pacific Arts Festival (Solomon Islands, 2012) and the Contemporary Pacific Arts Festival (Melbourne, Australia 2015).

\section{The Politics of Creativity and Tradition in Cook Islands performance}

Cultural performance is a key site in the imagining of the Cook Islands 'body-politic'. Dance, music, and oratory-all artistic forms involving aesthetic manipulation of the body in space-are central to the symbolical representation of collective identity, belonging and national pride. At the same time, cultural performances work to demarcate the boundaries between us and them, across a range of local, national and global contexts. Visiting officials are announced by beating drums, welcomed by dancers on arri$\mathrm{val}$, greeted with ceremonial chant, embraced with flower wreaths and may be presented with gifts of mats, hats and other decorative objects. These expressive welcoming protocols have been recorded in early European explorer and missionary accounts throughout the Pacific. They continue to initiate interactions with dignitary and in competitive displays such as sport; the haka performed by New Zealand rugby teams is perhaps the most well-known example from the region.
At the other end of the spectrum, the performing arts are a vital component of Pacific economies. Tourism is the Cook Islands main industry. On the main island of Rarotonga dancers perform weekly, if not more, at 'islandnights' held at hotels and restaurants and on board cruise ships. These performances are not simply 'staged' for the benefit of tourists; dance groups and individual members participate in a number of festivals and cultural competitions held throughout the year which are emblems of national pride. Some of these competitions, such as the annual composers contest and drumming competition, 'Dancer of the Year' competitions as well as beauty pageants, while attracting keen local interest are in also enabled by the tourist industry (key players provide sponsorship for example). Tourism provides the financial incentive to form dance groups while at the same time developing performance skills in younger generations. Cultural performance then is situated in multiple overlapping contexts that encompass economic, social and cultural agendas and include national, regional and global configurations (Sissons, 1995, 1999; Alexeyeff, 2009).

Cultural performances are also highly significant to independence and decolonisation movements in the region. Colonial regulation, and often prohibition, of 'traditional' cultural practices became, in many parts of the Pacific, sites of politicised resistance. Especially from the 1960s, the revival of 'pre-colonial' art forms such as carving, tattooing, dance and drumming among other things, were subsequently revalued and came to be important resources through which to demonstrate cultural and ultimately, national autonomy. Regional events such as the South Pacific Festival of Arts (now, the Festival of Pacific Arts) first held in Suva 1972, were explicitly developed by Pacific leaders' concern about the lack of 'cultural pride'. Similar national festivals developed across the region with the aim to forge, maintain and develop 'traditional' national cultures. Since achieving independence in 1965, the Cook Islands have put considerable effort into fostering national pride through the arts. The first independent government, the Cook Islands Party considered cultural revival and preservation vital to self-governance thus establishing a House of Ariki (House of Chiefs) to act as a consultative body on issues related to custom and welfare of Cook Islanders, and a cultural division in 1972. This later initiative led to the establishment of a Ministry of Cultural Development in 1990 which houses archives, library, and museum and performance spaces. At the opening of the Culture Centre which houses this Ministry, the Prime Minister Geoffrey Henry similarly located cultural identity as central to Cook Islands nationalism stating: 


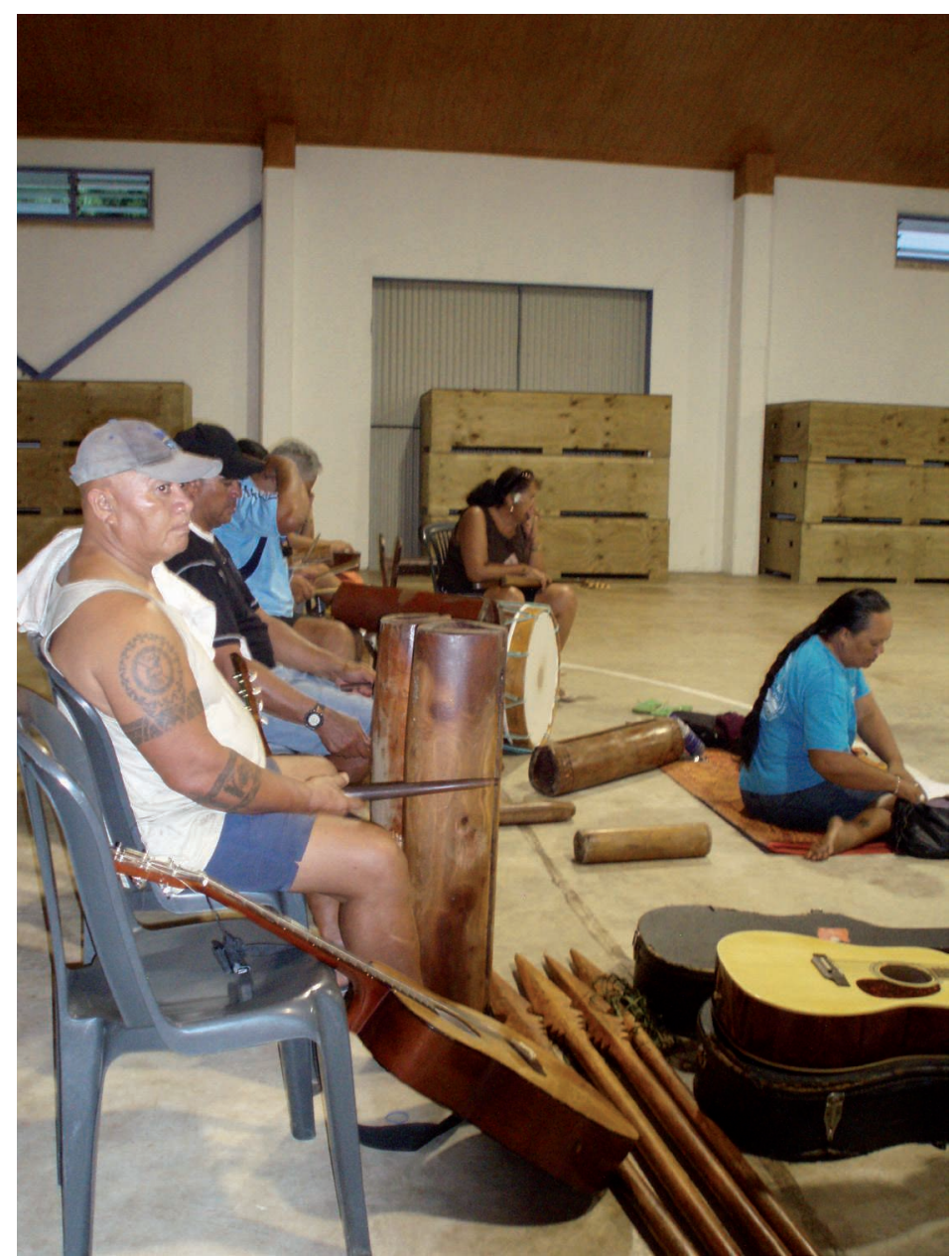

Рното 1. - Papa Dan Turua and other musicians at a dance group practice Rarotonga, 2011 (C Kalissa Alexeyeff)

"The life of the people is its culture. We, the custodians of the present have a duty today to future generations of Cook Islanders to preserve now, for their benefit, those special characteristics which identify us from other peoples and which will give them pride in their country and their heritage ... We must be courageous enough to preserve it by recording and teaching the very things which make us Cook Islanders, and different from others. " (MOCD, 1992: 5)

In the post-independence era, customs, traditions and cultural practices have become vehicles of political diplomacy. The Cook Islands National Arts Theatre (CINAT), formed in 1968, for instance, to promote a 'cultural renaissance' with a repertoire that included legends, dance, drumming and costumes representing cultural traditions from across the Cooks group. Over the years, CINAT performed at many Pacific Arts Festivals as well as touring Australia in 1970 for the Captain Cook bicentenary celebrations (Sissons, 1999; Alexeyeff, 2009). Dance groups also regularly travel to perform at events such as the Edinburgh Military Tattoo and as part of 'cultural exchange' visits with countries like
China who provide aid and development assistance to the Cook Islands.

Attempts to preserve cultural traditions are inevitably also accompanied by processes aimed at codifying and categorising what forms count as authentic traditions and what do not. These issues of legitimacy and ownership have been subject to much debate throughout Cook Islands post-independence history and reoccur in contemporary discussion about copyright as discussed in the following section. For instance, Albert Henry the Cook Islands first premier, held a Tumu Korero (holders of knowledge) conference in 1975, which brought together leaders and experts to discuss 'ownership' of artistic traditions as well as ways in which to record and preserve them. The conference involved often heated and highly competitive contests between this largely male group over rights to particular oral histories, graphic designs, chants and musical compositions. These debates over cultural property and authenticity are particularly evident during the annual independence dance performances originally called the 'Constitution Celebrations' which has been more recently renamed Te Maeva Nui (Alexeyeff, 2009: 50-51).

The Constitution Celebrations began in 1966 as a festival to celebrate self-government. Groups travel to Rarotonga at government expense to participate in a range of performing arts genres. While these events aim to promote national belonging and unity between the islands, they are also fiercely competitive events between island groups and increasingly dance groups from Cook Islander communities in Australia and New Zealand. The Constitution Celebrations performance guidelines for the main 'Festival of Dance' component encompass two main criteria. The first is to portray 'authentic' and traditional cultural forms and the second is to produce creative and novel performances. Inevitably, at certain points in the history of the Celebrations these two components have sat in tension; Festival organisers and government representatives have tended to stress 'authenticity' while performers have been more interested in producing innovative works within a broad Cook Islands style. This has led to numerous debates, recorded in local newspapers, letters to the editor and 
now online, where individuals attempt to define and contest what counts as tradition and what constitutes reasonable forms of innovation (see Alexeyeff, 2009: 57-83; Sissons, 1999).

Each year performance groups create new songs, choreography and music which may draw from local traditions and may also include current events and outside influences as inspiration. These innovations have, over the course of the last fifty years, been subject to scrutiny in terms of their traditional value and authenticity. Two main issues have been consistently raised, the first being copying of dance styles from other island groups, particularly those who won in previous years. This process is referred to as "copycatting" and it is a criticism of Rarotongan groups who utilise what are considered Northern group drum beats and is similarly levelled at groups from other islands who may 'copycat' Rarotongan costumes or particular dance moves.

The second issue raised with regard to the authenticity and traditional value of particular performances, is the hotly debated practice of "borrowing", which involves the incorporation of aesthetic forms from other parts of the world. In the early days of the Constitution Celebrations "borrowing" was particularly frowned upon. Members of performance groups have throughout the years protested that these instruments are now traditional, in the sense they have widespread usage and have been incorporated into a 'traditional' performance repertoire. Furthermore, it is likely that the guitar and tin drums were used as drum substitutes when locally made wooden drums were banned by missionary and colonial authorities. These substitutions or 'borrowing' take place within a larger context of cultural colonisation; they become embedded in artistic practice highlighting the entanglement of definitions of traditions with historical processes.

Despite public debate about what constitute Cook Islands traditions, performers and choreographers know that novel and innovative performances appeal to audience members. As one Ministry of Culture worker described "choreographers need to create something out of the ordinary to catch the attention of the viewers. Of course they stick to the original traditions but they add flavour to it to give it that uniqueness of their performances otherwise it will just be the same boring stuff over and over again" (Interview 11 September 2015). This person described hip hop moves that were incorporated into the choreography during the 2015 Maeva Nui competition, "When you look at it, it doesn't make you think that they are doing the papa'a [white] dance but they did it in a way that it looks like Cook Islands dancing". This process of 'borrowing' and also 'localising' outside influences is considered by many observers as extremely popular and entertaining. It is also an aesthetic practice that has a long history and over the years, sailor salutes, Kung Fu movements, Michael Jackson's 'moon walk' and disco have made appearances.

Both copycatting and borrowing are viewed in a number of complicated and overlapping ways that need to be considered in terms of broader cultural logics. The view of those who work as cultural representatives, such as Ministry of Cultural Development staff, whose role it is to both institutionalise and codify artistic forms may, in their official capacities, present copying and borrowing as a 'bastardisation' of traditional forms. For many choreographers, tradition and creativity are not necessarily oppositional but are both significant aspects of their practice. At the same time, these choreographers may complain, as well as accept as inevitable, that song tunes, choreography, drum beats and costumes are copied by rival dance groups from other villages or islands. Most copying and borrowing is not exact duplication but a reworking and reinterpreting of a drum beat, dance move, or costume. The aim of most creative practitioners is to produce new and innovative forms through this copying and borrowing. These two processes occur across all areas of social life, as one composer explained with an example far removed from performing arts, "it's like when a person may start a new business say for example, selling mud crabs and before you know it, everyone is copying you and selling crabs. It just always happens like that" (Interview 2011). Borrowing is also commonplace, in a society where reciprocity and demand-sharing are core values. 'Borrowing' that is, taking objects without asking, such as items of clothing, food and the like, while not always desirable are acts that are left unchallenged as it is understood that the same objects or other items are borrowed in return at a later stage.

This is not to say that musical composition or dance choreography are un-attributable to people or groups. Particular individuals and in some cases groups, are seen as having rights over particular drum beats, songs or choreography which are increasingly glossed as 'ownership. For instance, drum beats developed by the eminent composer Turepu Turepu in the 1970s like 'Fire' and 'Promotion' are played by drummers across the Cook Islands and amongst Cook Islands performers in other parts of the world. These performers acknowledge Turepu's authorship but there are no performance restrictions on his beats. While his authorship is acknowledged, some performers suggest that these beats are adapted from Tahitian ones he learnt when he was working in French Polynesia as a choreographer. In a similar way, songs especially are attributed to particular composers and are known as 'Mamia's song' or 'Tepoave's lyrics' and when recorded by 
other artists are acknowledged in the liner notes. In some cases, if the composer is alive and a performer wishes to use their work, they will visit and ask them permission to perform, as a sign of courtesy and respect. If original compositions are copied too closely and without acknowledgement, disputes, largely expressed through indirect means such as gossip, can arise. Indeed gossip, which acts to bring about public shaming of those who transgress certain social norms, has played and continues to play a significant regulatory function in Cook Island societies, as it does in many other close knit communities in the region and more broadly. Other forms of cultural production are also 'owned' for instance particular tivaivai quilt designs are considered to be the property of particular women. ${ }^{1}$ These designs may be 'gifted' to other family members who may copy them with permission and in such a way that ensures the owners are acknowledged. In these examples, a particular song or design may be considered to belong to individuals but they also simultaneously circulate through enduring and reciprocal social networks. Such local conceptions of rights over culture are in many ways at odds with western copyright laws that only accord protection for a limited period of time to works that are original and produced by an individual author.

Two agendas thus define artistic production and performance in the Cook Islands. The first agenda is of cultural maintenance and preservation. A series of state-based apparatus, including a national dance group, a government ministry devoted to cultural development, and festivals such as the Maeva Nui, take part in classifying and standardising aspects of 'traditional' and 'authentic' national culture. In the post-independence era culture served, as it continues to serve today, as a symbolic, political as well as an economic resource for the Cook Islands nation. The second agenda involves cultural innovation and creativity, a valued component of artistic practice and local reception. The two agendas while not necessarily oppositional have at certain points of the Cook Islands recent history been considered highly incompatible. This is perhaps most clearly seen in relation to issues surrounding 'borrowing' and 'copying' between the Cook Islands and French Polynesia. Prior to annexation, many of the islands that now make up the Cooks group had established economic, social and political links with islands that became the French colony. Colonial divisions did little to stop the networks that continued to flourish between these neighbours, including mutual exchange, borrowing and copying of drum beats, dance styles, costuming and song melodies (Moulin, 1996). Over the course of the last twenty years, claims of ownership have become an increasingly salient issue; while many Cook Islander artists continue to take inspiration or just simply reproduce Tahitian genres, the more dominant narrative in the Cook Islands is that Tahitian performers have stolen and importantly, made money, from their songs.

As others have noted, debates about cultural appropriation need to be understood in particular contexts. The interdependence of national and global economies and growing structural inequality between rich and poor countries and populations have particular impact on ideas of ownership and loss (Busse and Strang, 2011). In the Cook Islands 'culture' is a key economic resource for a small nation with few resources that can be converted into forms of capital (see McComb, 2012). Anxiety about ownership of cultural resources then assimilates broader concerns about the highly uneven 'playing field' of global capital and the relative disadvantage of the Cook Islands in comparison to larger countries and indeed, transnational corporations and enterprise. The colonial, and in many respects current, history of repeated and sustained exploitation of indigenous resources (land, labour, and resources such as trees or fish) by foreigners is also an important factor in the development of such anxieties. While as we have just outlined debate about cultural ownership and appropriation (copying and borrowing) have a long post-colonial history, it has taken on new dimensions particularly over the last twenty years as issues of copyright, intellectual property and notions of 'rights' more broadly have gained global traction. Now, issues of 'copying' and 'borrowing' may be framed as 'stealing' as more collective, relational and reciprocal notions of creativity circulate within a market-logic in which property adheres to individuals and may be bought and sold (Strathern, 2011; Guiffre, 2009).

\section{Types of intellectual property issues that arise}

As indicated in the previous section and in other articles in this special edition, dance, music and other cultural performances are today being performed in numerous different contexts and locales. Public performances at local, international and regional festivals and the ease of capture and reproduction through digital technology and the internet give rise to anxieties about copying, stealing and authenticity. The increasing preva-

1. Tivaivai are appliqued quilts and cushion covers. Quilting was introduced by missionaries and are now thought to 'belong' to the Cook Islands, the patterns, designs and sewing techniques have been indigenised by practitioners. (Küchler and Eimke, 2009). 
lence of intellectual property rights discourse in the region, particularly as generated by organisations such as the World Intellectual Property Office, unesco, the Secretariat of the South Pacific Commission and national performing rights associations, means that legislation, particularly copyright and traditional knowledge laws, are being suggested as offering a solution to these anxieties (see for example McComb, 2012).

This section discusses the ways in which the issues identified in the previous section, namely concerns around 'copycatting', 'borrowing', cultural maintenance and preservation have underpinned the drive towards the adoption of new intellectual property laws in Cook Islands. It focuses particularly on the parliamentary debates in the Cook Islands parliament during 2013 when both the Copyright Bill and Traditional Knowledge Bill were debated. Significantly, the second agenda we described in the previous section, involving cultural innovation and creativity, is far less commonly drawn upon in the push for new legislation.

The concern that music or dance that is said to belong to a particular individual, tribe, island or community is being misappropriated by outsiders and commercially exploited has been a strong driver of legislative change. As noted above, in the Cook Islands context this is a particular complaint with regard to Tahitians and Hawaiians who are widely believed to steal particular musical beats, song compositions and even dance moves. ${ }^{2}$ One Cook Islands composer observed "When Tahitians sing our songs it sounds more beautiful than when we do, but it is ours" (interview with Vereara Taripa, Cook Islands, 5 November 2014). There is particular frustration at the fact that Tahiti has a performing rights association, a branch of a French organisation, SPACEM. In the Cook Islands there are many conflicting stories about the efficacy of this organisation, with many believing that registering a song with such an organisation can lead to significant financial benefits. Tahitians are frequently reported as able to profit from this by registering Cook Islands songs as their own. However, there are also concerns that misappropriation is taking place at both a global level, particularly through the medium of the internet, and also at local and national levels, such as through annual dance festivals. Cook Islands MP Ione expressed the concern as follows: "with the capturing on tape our Cultural performances in our National Auditorium and those people who are taking shots, can just go and reproduce this and generate income for them" (MP Ione, Cook Islands Parliament Hansard, Wed 4 December 2013, p 18). Another MP observed:
Likewise with our quilting we have shared this with foreigners and afterward they took the knowledge of quilting and started making money for themselves. Likewise with our DVD productions that we have been producing locally with regard to our drumming and the beat and foreigners came and took the tape and learned from there, readjusted to be more conducive to their culture. (Second reading speech, Cook islands Parliament Hansard, Wednesday 4 December, p 12, Mrs N Munoka MP)

Intellectual property laws, in particular copyright, and the establishment of copyright collecting agencies, are widely considered to be an appropriate way to respond to these concerns. In the 2013 debate following the second reading of the Copyright Bill in the Cook Islands parliament, members of parliament supported the Bill unanimously. There was repeated reference to the fact that one of the Bill's main purposes was to "register and retain the ownership of certain aspects of our culture so that no foreigner can claim it" (Mrs S. Napa. Cook Islands Parliament Hansard for Wednesday 4 December 2013, p7).

Another MP commented that it would

" turn our culture, all these things very important to our country, to each island, to each people. Maybe in the future these things will become so valuable. Owners of those rights might make money on them. "

Perhaps unsurprisingly, there is little reflection on the appropriation of foreign music by Pacific islanders. Pacific scholars have noted that the long history of musical borrowing as a process of creative synthesis of imported and local musical forms (Moulin, 1996; Thomas, 1981). Cook Islands popular music performed by 'string bands' that combine Western melodies and musical genres (such as popular Latin, reggae and pop music) with local rhythmic, percussive and tonal systems. As an example, the song, 'If I Said You Had a Beautiful Body (Would You Hold It Against Me)' by the Bellamy Brothers, had been adapted by Cook Islands bands over the years, and given Cook Islands as well as English lyrics. Hawaiian inspired popular hits such as 'Pearly Shells' and 'Beyond the Reef' have similarly been adopted and adapted string band music may also include segments of Cook Islands chant ( $p e^{\epsilon} e$ ) or secular song styles ('ute) (Alexeyeff, 2004). As a local Cook Islands radio operator observed, "Our musicians are notorious for plagiarising but they do not see it like that" (Interview 4 November 2014). He continued, Cook islanders "islandify" international music, but they do not go through the process of getting the rights to do so; it is an arduous process for them.

2. One dance troupe manager complained that in the past dancers from Niue did not swing their hips, this was a Cook Islands style, but now Niuean ladies are "trying" to use their hips 
The second category of concern is that of erosion of "traditional" dance and song, such as the introduction of new dance movements from outside the country or even the region, or the homogenisation of dance and song as a result of too much mixing and sharing of performances. For example, the leader of a dance troupe in Cook Islands spoke with horror of a recent dance he had seen that imported ninja turtle moves, and expressed concern that such practices would lead to loss of traditions. Rather than viewing this as an innovative cultural practice he stated that he hoped that the Ministry of Culture would "do something about" such practices (Interview with a dance troupe operator, Cook Islands, 6 November 2014). He also expressed concern that dance groups in the past ten years have started to combine styles of dancing from the Southern and Northern groups and that this may lead to a loss of culture in each island. Similarly one MP stated:

«I would also encourage the Ministry of Culture to be mindful of the unique feature of our dancing for instance on the respective islands. Because our annual celebration to celebrate our anniversary of internal self-government has in a way influenced and the changes that is taking place is evident with regard to our performing arts. In my own observation the influences of the performing arts from Rarotonga in influencing islands such as Mangaia [...] The Ministry should look at how we are going to enforce to capture the essence of each island's unique way of presenting their culture. " (MP S Napa, Hansard p 9, Tuesday 3 Dec 2013)

Legislation, together with registers that ascribe rights over certain aspects of cultural heritage to particular communities and groups, are perceived by many throughout the region as being a way to prevent such unwanted mixing up and intrusion of foreign influence as discussed in the next section.

Registers and legislative rights also raise the issue of authenticity; namely being able to define what is and is not authentic and also to prove authenticity and brand it for the purposes of engagement with tourists and other outside consumers. Issues of authenticity are also closely tied to questions of who has the right to decide what is authentic and what is not, and what forum such questions are to be determined in. In the parliamentary debates over the new copyright and traditional knowledge legislation there were repeated references to ensuring that "the right knowledge, the right traditions" (Cook islands Parliament Hansard, Wednesday 4 December 2013, MP T Heather, p 21) are collected, and issues raised about whether some traditional knowledge teachings and institutions are "true" or not (Cook islands Parliament Hansard, Wednesday 4 December 2013, MP T Tura, p.20). Informants in fieldwork also frequently observed that the "right" people are needed to teach the "proper" way to dance and sing and compose. In turn, performers noted that visual transmission and copying were also important to the reproduction of "authentic" traditions. One MP (W Rasmussen, Hansard, 4 December 2013, p. 25) stated for instance that: "There were lots of us in our generation and maybe generations before that who were able to observe the gestures and intonations of the voices of the people that were performing the oral arts, the oral traditions and it's by learning those that you actually give it some authenticity when you are trying to repeat those on occasions". The increasing recourse to intellectual property laws and statutory frameworks prioritise the state and the courts in such determinations, at the expense of local and customary institutions and agency, although as in the Cook Islands legislation discussed below there is often an attempt to involve local institutions in these determinations.

Finally a group of concerns about cultural heritage and loss precipitated the legislation. This is particularly pronounced in the Cook Islands as a result of a continual flow of external migration and consequent depopulation. Again, legislation is envisaged as one mechanism to overcome the decline in traditional knowledge. One MP commented that the Bill would "preserve these customs and traditions $[\ldots]$ so that the future generation will have a pool of resources to draw from." Another stated that there "are things worth learning about our traditions and culture and that is why there is this Bill" (Cook Islands Parliament Hansard for Monday 2 December 2013, p 22, MP M Ioane). A further observed there is a "need for an Act of Parliament for us to ensure a strong foundation for our traditions and customs" (Cook Islands Parliament Hansard for Tuesday 3 December 2013, p10, MP J Henry). Legislation is seen as a way of publicly recognising the worth of traditional knowledge and cultural heritage, particularly as it is a mode of recognition that is seen to resonate with the younger generation and the international community. One MP observed that before the passing of the Bill music and songs had no value, and yet "with the passing of this Bill, to me we now see the registration of these cultures becomes a most valuable asset for all Cook Islanders" (Cook Islands Parliament Hansard for Tuesday 3 December 2013, p10, MP T Vavia).

A related motivation behind the push for this legislation is a concern to find some mechanism to acknowledge and pay respect to the individuals or communities behind the particular element of cultural heritage or performance. This desire strongly resonates with customary institutions and regulatory systems around knowledge and performance that existed in many parts of the Pacific islands and continue to exist up to the present. A Cook islands MP stated "due ac- 
knowledgment ought to be given to the original composers of the songs or chants or whatever and that is why I stand to give my support to this Bill” (Mrs S. Napa, Hansard, Wednesday 4 December 2013, p7).

\section{Regulatory responses and issues arising}

The different categories of concerns described in the previous sections have played a large role in motivating many Pacific Island countries to introduce or strengthen copyright laws and also to develop legislation aimed at protecting traditional knowledge. ${ }^{3}$ The Pacific Islands Forum Secretariat commenced an initiative in 2009 to fund seven pilot countries to develop and pass traditional knowledge legislation, ${ }^{4}$ but to date Cook Islands and Niue are the only two Pacific Islands countries to have actually enacted such legislation. ${ }^{5} \mathrm{At}$ a regional level there has also been considerable action in this regard, with the development of the Melanesian Spearhead Group Treaty on Traditional Knowledge (still unratified), the Pacific Model Law for the Protection of Traditional Knowledge and Expressions of Culture 2002, and the Pacific Model Traditional Biological Knowledge, Innovations and Practices Act 2001 and associated Guidelines (Pacific Islands Forum Secretariat, 2010). However, this article focuses primarily on the developments in the Cook Islands.

In 2013 Cook Islands parliament passed the Copyright Act 2013 (available at http://www.wipo. int/edocs/lexdocs/laws/en/ck/ck001en.pdf). In contrast to the 161 countries of the world that in April 2015 are members of the World Trade Organisation and thus obliged to enact copyright legislation as a result of the Agreement on Trade Related Aspects of Intellectual Property (TRIPS), the Cook Islands was not compelled by any free trade agreement to enact these laws. The primary motivation for the copyright act appears to be a desire to safeguard the rights of Cook island composers and performers. Such considerations have played an important role in other Pacific Island countries' copyright development (see Forsyth, 2013b; Forsyth, 2015). Importantly however, it must be noted that the Cook Islands has not as yet ratified the Berne Convention which establishes the global copyright system and which obliges member states to protect the copyright of citizens of other member states. As a result of not ratifying this Convention, at present the Cook Islands Copyright Act only applies to Cook Island authors and does not extend to allowing such authors to enforce their rights in other countries (and by the same token foreign authors cannot enforce their copyright in Cook Islands). Like other copyright acts, this Act gives the authors of original works that have been fixed in material form a range of exclusive rights, including the right to prevent copying the work. It also contains provisions regarding moral rights and performers rights. This Act has not been actively implemented to date, and no collecting societies to collectively collect royalties as exist in many other countries around the world have been established, although in 2015 a workshop was held to discuss how the Ministry of Culture plans to "give local musicians the tools necessary to protect their material (see http://pidp.eastwestcenter.org/pireport/2015/ April/04-23-15.htm).

In 2013, the Cook Islands parliament also passed the Traditional Knowledge Act 2013 and indeed the two pieces of legislation were viewed as being like a "Mother and daughter" and "double canoes that take our people across oceans." (Hansard 4 December 2013, p. 15, Hon T Bishop MP). As Forsyth and Haggart (2014) have argued, the frequent conflating of legislation seeking to protect traditional knowledge with global intellectual property frameworks (such as the Agreement on Trade Related Aspects of Intellectual Property that provides the framework for the global intellectual property treaty system), has problematically led to many incorrect assumptions about how such laws will operate and the benefits they will bring. They argue $(2014,220)$ :

"Whilst intellectual property regimes are part of an established international framework that facilitates their enforcement globally through TRIPS and complicated web of FTAs, traditional knowledge is not currently protected outside national borders, and often not even within them. Dealing with the two issues together in FTA negotiations means that these fundamental differences are difficult for those not trained in intellectual property to perceive, and there is an implicit suggestion of equal treatment. "

They also note that there is a widespread perception that global intellectual property laws are valuable in preserving culture, and no discussion

3. At a national level in the Pacific Islands region, there is draft legislation in a range of countries (Fiji, Vanuatu, Samoa, Solomon Islands) and the Cook Islands recently enacted its Traditional Knowledge Act 2013. There are also specific provisions relating to traditional or indigenous knowledge in a range of existing pieces of intellectual property regulation. For example Part 7 of Vanuatu's Copyright and Related Rights Act 2000, and section 30 of Samoa's Copyright Act 1998.

4. The Act is also part of an ongoing international movement to protect traditional knowledge as well as a series of regional initiatives. There are discussed in Forsyth 2012, Forsyth 2013.

5. Tāoga Niue Act 2012. 
about any potential disadvantageous development consequences. This has led to intellectual property maximalist policies being unquestioningly introduced in some Pacific island countries with not enough skepticism of the potential negative impacts on development of such laws, such as increasing the costs of pharmaceuticals, seeds, foreign technology and knowledge generally.

Like the Copyright Act, the Traditional Knowledge legislation also only has effect domestically as there is currently no international treaty for traditional knowledge (Forsyth, 2013). This section discusses three aspects of the Act: the role of the register, the relationship between the state and customary authorities, and issues of entitlement with regard to Cook islanders living overseas.

One of the main ways that the Traditional Knowledge Act is intended to operate is through the establishment of a register of traditional knowledge. Registers of traditional knowledge are an increasingly familiar component of Pacific Islands governments' and other institutions and researchers' responses to concerns over cultural heritage (Leach and Nombo, 2010; wHO, 1998; Hidving, 2005; Taafaki, Fowler and Thaman 2006), and indeed world-wide (wIPO, 2015). The most well-developed is Fiji's National Inventory Project that commenced in 2004 and continuing today with the objective of mapping all its cultural heritage, including traditional medicine, in every village in Fiji (Teaiwa and Mercer, 2011). There are also national traditional knowledge databases in New Caledonian and Palau. Vanuatu also has a tabu room and a database (UNESCO, 2012: 58). This is supplemented on an international level by UNESCO's registers of intangible cultural heritage, on which Vanuatu sand drawing and Tongan lakalaka dances are inscribed. The creation of registers and careful documenting of subject matter and rights owner is one way to respond to anxieties about both knowledge loss and lack of authenticity. However, the creation of such registers raises a whole range of issues that are often over-looked, including the 'fixation' of traditional knowledge in a particular time, de-contextualisation of knowledge, the difficulties of both creating and restricting access, and future claims that may be made using the authorship information assigned in the process of making the collection.

The Cook Islands Traditional Knowledge Act establishes a register whereby those claiming to be right-holders can register their traditional knowledge, and as a result are granted certain exclusive rights, including "to use, transmit, document or develop the knowledge in any way (whether commercial or not)" (Section 7(1)a). The rights-holders of the knowledge are those who either created the knowledge or who are the customary successor to the knowledge. The register, which is to record a general description of the knowledge, is to be maintained by the Secretary of Cultural Development and to be available for inspection at the offices of the Ministry, unless the Secretary considers that "it is not practical to provide access to the register at that time." However, the general nature of the description of the knowledge required to be recorded, and the relative inaccessibility of the register raise doubts about whether the register will in fact provide any clarity over what traditional knowledge is actually being claimed and by whom. The slight variations in knowledge from one island to another make it likely that many different variations would be able to be registered, also making it hard to determine who the rights holders actually are.

The Traditional Knowledge Act attempts to bring customary institutions into the regulatory framework by giving decisions over questions of who the true rights-holders are to a local institution called the Are Korero ("House of Knowledge"). Whilst there was a degree of confusion amongst informants as to the exact nature of an Are Korero, it appears to refer to an institution that used to exist that facilitated the sharing of knowledge held by the different experts in healing, fishing, navigation, chanting, composing, dancing, weaving and so forth. The Act envisages the Are Korero will be re-invigorated and that the relevant paramount chiefs will decide who constitutes the Are Korero for their particular island or area. This provision for making determinations about rights over traditional knowledge at local levels is a major improvement on previous frameworks that give such decisionmaking power to state or regional authorities (see Forsyth, 2011; Forsyth, 2012). However, the creation of the Are Korero is also not without problems. Aside from the practical difficulties of establishing and resourcing these institutions, there are also challenges to their authenticity and to the legitimacy of the chiefs who appoint them as disputes over chiefly title is common throughout the country. Further, the designation of authority to the Are Korero is perceived by the current President of the House of Ariki, the constitutionally mandated paramount customary authority in the Cook Islands, as sidestepping its role and authority. He observed that it is the House of Ariki's responsibility to support, cultivate and promote traditional knowledge and as such it should be the House of Ariki that makes the final decision about how traditional knowledge is used (interview with President, 11 November 2014, Cook Islands). This controversy over which institution

6. Section 60(2). This arrangement in fact accords with the way in which access to legislation is currently provided in Cook Islands: it is only available upon personally going and paying a fee for a copy at parliament house. 


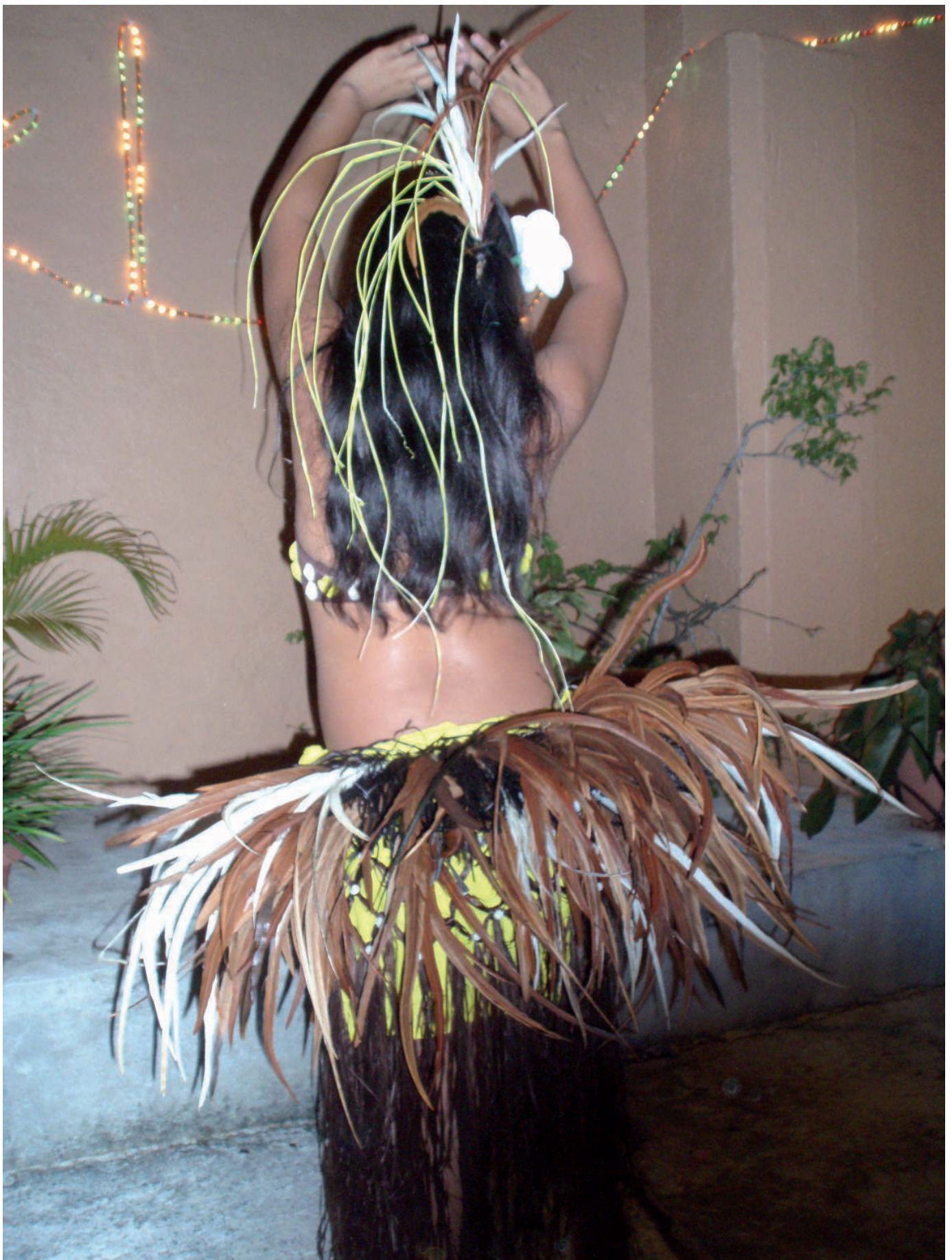

Рното 2. - Young Dance at a dance competition with innovative feather costume design, Rarotonga, 2011 (C) Kalissa Alexeyeff)

has the power to decide questions of authenticity and entitlement is at the heart of many of the debates over cultural performances and their misappropriation. In this way, we see how anxieties and concerns about cultural performances have repercussions and roots in fundamental questions of governance and legitimacy more broadly.
The final aspect of the Act to discuss is the rights accorded to those Cook Islanders living overseas, who significantly outnumber those remaining at home (approximately 8:1). ${ }^{7}$ According to one informant, in an earlier version of the Act, Cook Islanders living outside the Cook Islands were not able to register any rights over their traditio-

7. The Cook Islander population in New Zealand was 62,000 in 2013. In Australia an estimated 10,000 compared to 14,000 in the nation-state. 
nal knowledge. Although the current version of the Act does allow this, it must be done through the Are Korero of the person's home island. Cook Islanders living overseas are also disadvantaged: the Act only requires that information about the application is placed on the noticeboard or other usual place for notices on the island (section 22(2)), making it difficult for a community member living off the island to stay informed. This issue is symptomatic of broader concerns and debates about the entitlements of those who have migrated, a huge issue in relation to land and titles in Polynesia and likely to become more prevalent in regard to culture and cultural performance as well. The President of the House of Ariki observed that the people who have migrated leave the ones behind to do all the work of preserving for them; and if they want to claim rights then they should come home to do it (interview 11 November 2014, Cook Islands). The potential of the law to be used by those who remain at home against those living in the diaspora is clearly present. This is compounded by the different world views that these different communities sometimes embody. For instance, a Tongan artist living in New York observed:

«People say 'you have no right to do something, you can't even speak the language' [...] Sometimes [my friends] go back to their home countries and then they return and say "people don't accept my artwork." [...] Of course my art comes from the streets of South Bronx so it is different to the artwork of someone living in Tonga. [...] I am all for creation. I am all for respecting our traditions as well. But I live in a completely different world to someone raised in Tonga. (Interview with Vaimoana Niumeitolu, 15 April 2014 (telephone, Canberra and NY)

\section{Discussion and Conclusion}

A number of issues have emerged from the preceding discussion, including the use of law to control culture; the impact of new legislation on the sharing and exchange of cultural performance; and the potential of legislation to impose new epistemic practices on artists.

The new Cook Islands legislation is a recent example of an emerging trend in Pacific island countries to use both global intellectual property rights instruments, such as copyright, and sui generis laws, such as traditional knowledge legislation, to control aspects of culture. There has been an explosion of interest in intellectual property regulation in the region over the past decade, with many national governments establishing new intellectual property offices, updating and introducing new legislation, and drafting new frameworks and policies to protect traditional knowledge and expressions of culture. In this regard it must be borne in mind that the law is never neutral and the creation of new rights always advantages certain groups and disempowers others, in particular the creation of boundaries of private ownership creates tension with principles of public access (Gallagher, 2009). In this regard in the Cook Islands it seems the new laws will advantage those living in the Cook Islands over members of the diaspora.

An important question that has driven this paper is what impact will these new actual and imagined laws and restrictions have on existing ways of sharing knowledge and cultural performances? Will the laws fail to be instrumentalised in practice as many predict? Or will they be selectively enforced against those perceived as "outsiders" only and not interrupt ongoing processes of cross-fertilization. Henry and Foana ota (2015: 139) insightfully observed that although there was a great deal of formal discussion and concern about protection of cultural heritage, at the most recent Festival of Pacific Arts: "Festival participants engaged in a dynamic process of cultural composition and performance, which entails the diplomatic development of relationships that challenge attempts by the corporate state to control dynamic cultural practices by capturing them within a heritage regime." As we have argued throughout this paper, heritage or traditions are not necessarily in opposition to creativity and innovation, but rather the two are articulated in culturally specific ways. However there have been numerous attempts in the post-colonial era, to systematise Cook Islands traditions through museums, archival and anthropological research, national festivals, and increasingly through the instruments of Traditional Knowledge and Copyright acts.

There is also the concern that these legislation regulating traditional knowledge and copyright may lead to exclusionary claims being made, with increasing attention paid to concepts of exclusive property rights and ownership, as well as issues of cultural appropriation and commoditisation. This process is akin to what Filer (1996) has termed an 'ideology of land ownership' that developed in Papua New Guinea with the rise of private land tenure rights. One Cook Islands participant expressed concern that these new laws may prevent culture from changing, and hence appealing to the youth, noting that it has to keep changing or else it will disappear (interview, anonymous, Cook Islands 15 November 2015). The narratives that surround the impetus for new intellectual property laws in this field are often based upon the trope of misappropriation by foreigners, yet today the picture is far more complex. The ownership or right to knowledge is a deeply political process within communities. For example, in the 2015 Melbourne Moomba festival (Australia) there was an issue involving 
the inclusion of a $d u k d u k$ figure in a parade by one group of Papua New Guineans that was strenuously objected to by another group on the grounds that to them it is a sacred ancestral figure that belongs to their tribe (LaFargue, 2015). There is a risk that the current framing of these issues within a discourse of intellectual property rights drives an approach to the regulatory framework that closes down options for exchange of practices and knowledge. On the other hand, it could be argued that the existence of this legislation creates a feeling of security within which knowledge and artistic expression can be more freely shared, because there is not the concern that the person sharing will be exploited (this point was made in an interview with local Cook islands artist Mahiriki Tangoroa 15 November 2014, Cook islands).

A final issue concerns the epistemic basis of performance in Cook Islands and the Pacific islands in general; it is self-consciously based on copying and repetition as well as by oral and visual transmission. Through this process innovation and creativity occurs. This is very different to copyright and traditional knowledge registers that are based on fixation of knowledge or performance in material form and the prohibition on copying without seeking permission or payment. Concern about cultural misappropriation while clearly reflecting the structural inequalities experienced by marginalised and colonised cultures are expressed in static ways that elide processes of creativity and dynamism. In this way copyright and traditional knowledge registers may significantly inhibit drivers of creativity as, "...in defending the rights of subordinated people to protect the integrity of their culture and to control its use, most of the discourse of cultural exploitation operates from a model of culture as clearly bounded and distinct, as singular and organic" (Rogers, 2006: 478).

As an attempt to establish cultural ownership and to stave off misappropriation the new regulatory frameworks have paradoxical effects. In promoting exclusive rights and ownership, these laws have the potential to significantly affect traditions of cultural production as well as social relationships more generally. While commoditisation occurs on a daily basis, Cook Islanders have also maintained flexible networks of exchange that operate outside market logic. Property and ownership are based in social relationships that are transformed through practices based in reciprocal borrowing, exchange and copying. These processual ways of knowing and being could be curtailed through the implementation of legal registers. One Cook Islander interviewee observed that the traditional knowledge legislation may restrict Cook islander affiliations and social obligations because sharing of knowledge is a critical way of maintaining linkages between people, both within the country and externally (Interview with herbal medicine man, Cook Islands market, 11 November 2014). Cook Islands creativity as a social phenomenon takes place within particular reciprocal networks of relationship, and these networks are highly likely to be impacted by narratives of copyright and rights over traditional knowledge.

\section{BIBLIGRAPHY}

Alexeyeff Kalissa, 2004. Sea Breeze: Globalisation and Cook Islands Popular Music, The Asia Pacific Journal of Anthropology 5, pp. 145-158.

-, 2009. Dancing from the Heart: Movement, Gender and Cook Islands Globalization, Honolulu, University of Hawai'i Press.

Gallagher William (ed.), 2009. Intellectual Property, Farnham, Ashgate.

Giuffre Katherine, 2009. Collective Creativity: Art and Society in the South Pacific, Farnham, Ashgate.

Henry Rosita and Lawrence FoAnA'Ota, 2015. Heritage Transactions at the Festival of Pacific Arts, International Journal of Heritage Studies 21, pp. 133-152.

Forsyth Miranda, 2011. The Traditional Knowledge Movement in the Pacific Island Countries: the Challenge of Localism, Prometheus 29, pp. 269-286.

—, 2012. Do You Want it Giftwrapped? Protecting Traditional Knowledge in the Pacific Island Countries, in P. Drahos and S. Frankel (eds), Indigenous Peoples' Innovation: IP Pathways to Development, Canberra, ANU ePress, pp. 400-451.

—, 2013a. How Can Traditional Knowledge Best be Regulated? Comparing a Proprietary Rights Approach with a Regulatory Toolbox Approach, The Contemporary Pacific 25, pp. 1-31.

—, 2013b. The Developmental Ramifications of Vanuatu's Intellectual Property Commitments on Joining the World Trade Organisation, Journal of Pacific Studies 36, pp. 157-172.

—, 2015. Intellectual Property Policy in Pacific Island Countries: Who is Really Playing the Tune?, SSGM in Brief 2015/38, (http://ips.cap. anu.edu.au/ssgm/publications/intellectualproperty-policy-solomon-islands-who-reallyplaying-tune, accessed 8/12/15).

Forsyth Miranda and Blayne Haggart, 2014. The false friends problem for foreign norm transplantation in developing countries, Hague Journal on the Rule of Law 6, pp. 202-229. 
Kuchler Susanne and Andrea Eimke, 2009. Tivaivai: the Social Fabric of the Cook Islands, London, British Museum Press.

Nombo Porer and James Leach, 2010. Reite Plants. An Ethnobotanical Study in Tok Pisin and English, Canberra, ANU EPress.

Мссомв Jessica, 2012. Developing and Marketing Strategies for Pacific Islands Cultural Industries, Secretariat of the Pacific Community, (http://www.spc.int/DigitalLibrary/ Doc/HDP/Culture/51404_Development_ and_marketing_strategies_for_Pacific_cultural_industries.pdf, accessed 8/12/15).

Ministry of Cultural Development, 1992. Second Annual Report 1991-1992, Rarotonga, Cook Islands.

Moulin Jane, 1996. What's Mine is Yours? Cultural Borrowing in a Pacific Context, The Contemporary Pacific 8, pp. 128-153.

Lafargue Caroline, 2015. Who owns Traditional Arts?, Radio Australia (http://www.radioaustralia.net.au/international/2015-04-23/who-ownstraditional-arts/1438124, accessed 8/12/15).

Rogers Richard A, 2006. From Cultural Exchange to Transculturation: A review and reconceptualization of cultural anthropology, Communication Theory 16, pp. 474-503.

Sissons Jeffrey, 1999. Nation and Destination: Creating Cook Islands Identity, Rarotonga, Institute of Pacific Studies and the University of the South Pacific Centre in the Cook Islands.

—, 1995. National Movements: Dance and Nationhood in the Cook Islands, Sites 30, pp. 153-164.

Strang Veronica and Mark Busse (eds), 2011. Ownership and Appropriation, Oxford and New York, Berg.

Strathern Marilyn, 2011. Sharing, stealing and borrowing simultaneously, in V. Strang and M. Busse (eds), Ownership and appropriation, Oxford and New York, Berg, pp. 23-42.
TAafaki Irene J., Maria K. Fowler and Randolph R. Thaman, 2006. Traditional Medicine in the Marshall Islands: the Women, the Plants, the Treatments, Suva, Institute of Pacific Studies.

Teaiwa Katerina and Colin Mercer, 2011. Pacific Cultural Mapping Planning and Policy Toolkit, Noumea, Secretariat of the Pacific Community. (http://www.acpcultures. eu/_upload/ocr_document/SPC_PacificCultMapPlanPolToolkit_2011.pdf, accessed 13/04/2015).

Thomas Alan, 1981. The Study of Acculturated Music in Oceania: "Cheap and Tawdry Borrowed Tunes"?, Journal of the Polynesian Society 90, pp. 183-191.

UnesCo, 2012. Intangible Cultural Heritage, Safeguarding Efforts in the Asia-Pacific, Vanuatu Field Survey Report, International Information and Networking Centre for Intangible Cultural Heritage in the Asia-Pacific Region under the Auspices of unesco. (http://www. ichcap.org/eng/ek/sub1/pdf_file/pacific/Vanuatu_pdf.pdf, accessed 12/04/2015).

Hviding Edvard, 2005. Reef and Rainforest: $A n$ Environmental Encyclopedia of Marovo Lagoon, Solomon Islands/Kiladi oro vivineidi ria tingitonga pa idere oro pa goana pa Marovo, Paris, unEsCO, Knowledges of Nature Series 1.

World Intellectual Property OrganizaTION, 2015. Online Databases and Registries of Traditional Knowledge and Genetic Resources, (http://www.wipo.int/tk/en/resources/db_registry.html, accessed 8/12/15).

World Health Organization, 1998. Medicinal Plants in the South Pacific, Manila, Centre for Traditional Medicine, WHO Regional Publications Western Pacific Series 19.

XIong Ping, 2008. Traditional Knowledge and intellectual Property protection: the Endeavour of Niue, Revue juridique polynesienne 14, pp. 123-134. 
Disponible sur le site internet de la Société des Océanistes (http://www.oceanistes.org/oceanie/ spip.php?article3891) et à la librairie du musée du quai Branly au prix de $19 €$.

Version pdf disponible sur http://books.openedition.org/sdo/1213 au prix de 14,99€.

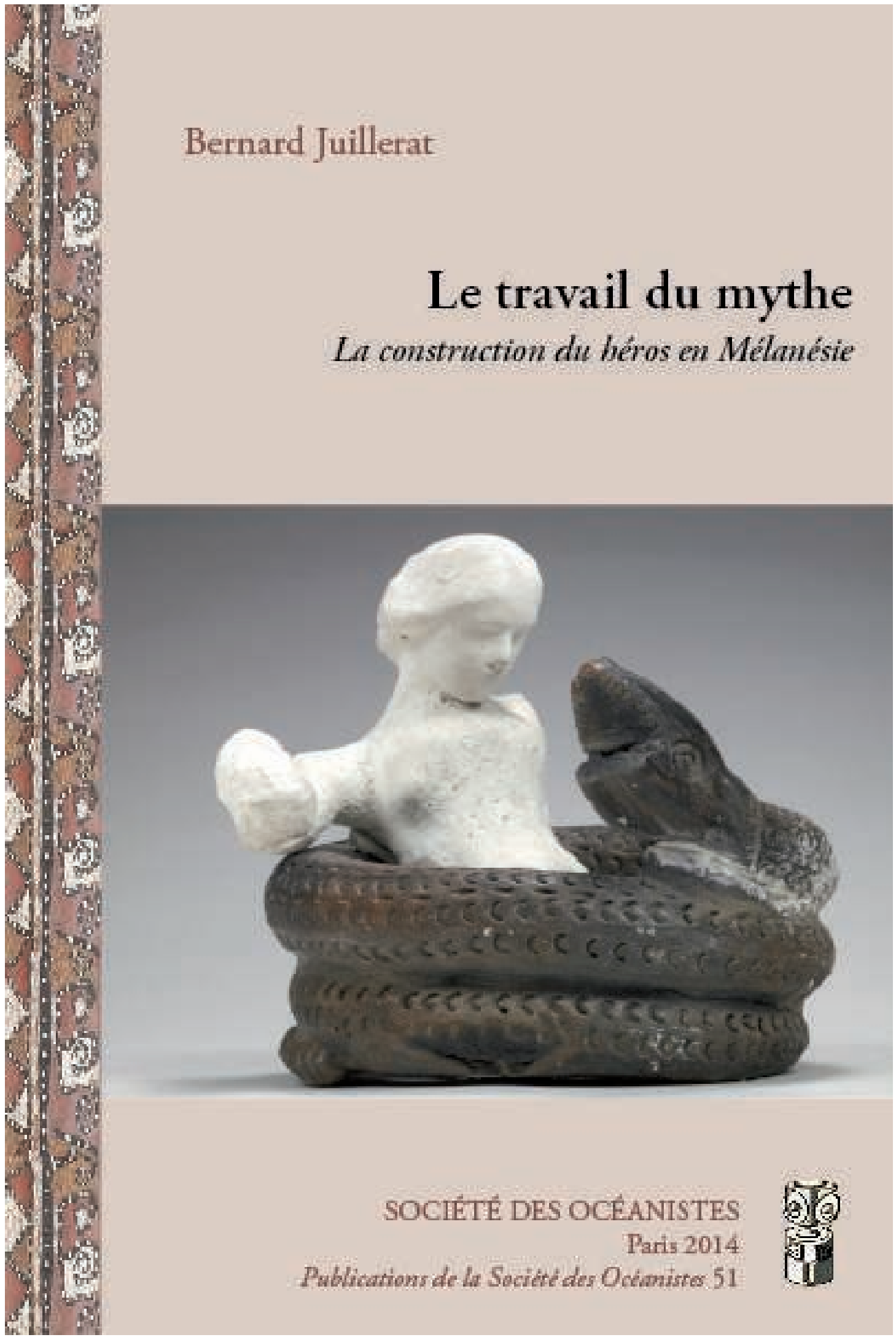

